\title{
PENGARUH PENERAPAN TAK : PERMAINAN KUARTET TERHADAP KEMAMPUAN SOSIALISASI PADA PASIEN ISOLASI SOSIAL
}

\author{
Retno Yuli Hastuti ${ }^{1}$, Nur Wulan Agustina ${ }^{1,}$ Surya Hardyana ${ }^{1}$ \\ ${ }^{1}$ Program studi keperawatan, STIKES Muhammadiyah Klaten \\ hastuti.puteri@gmail.com
}

\begin{abstract}
ABSTRAK
Salah satu tanda gejala negatif skizofrenia adalah isolasi sosial. Angka kejadian gangguan jiwa mencapai 2,3 permil dari jumlah penduduk. Langkah yang dapat diberikan untuk memfasilitasi pasien isolasi sosial social untuk melakukan sosialisasi secara bertahap melalui kegiatan permainan sosialisasi kelompok yaitu berupa terapi aktivitas kelompok menggunakan kartu kuartet. Penelitian ini bertujuan untuk mengetahui pengaruh penerapan TAK : permainan kuartet terhadap kemampuan sosialisasi pada pasien isolasi sosial di RSJD Dr. RM. Soedjarwadi Provinsi Jawa Tengah. Jenis penelitian ini adalah quasy eksperimen dengan desain penelitian pre and post test without control. Jumlah sampel dalam penelitian ini sebanyak 13 responden. Tehnik pengambilan sampel menggunakan purposive sampling. Uji statistik bivariat menggunakan uji Wilcoxon. Rata-rata umur responden dalam penelitian ini adalah 28,54 tahun dengan jenis kelamin laki-laki 7 orang. Tingkat pendidikan terbanyak SMP dengan jumlah 6 orang atau 46,2\%. Pekerjaan responden terbanyak yaitu tidak bekerja 8 orang atau $61,5 \%$. Kemampuan sosialisasi sebelum dilakukan intervensi TAK permainan kuartet tergolong kurang sebanyak 7 atau 53,8\%. Sedangkan kemampuan sosialisasi setelah dilakukan intervensi TAK permainan kuartet terjadi peningkatan dimana kemampuan sosialisasi yang baik menjadi 10 orang $(76,9 \%)$, dan penurunan pada kemampuan sosialisasi yang kurang menjadi 1 orang $(7,7 \%)$. Hasil uji statistik dengan uji Wilcoxon diperoleh nilai $p$-value 0,003 atau $(\alpha<0,05)$. Ada pengaruh penerapan TAK : permainan kuartet terhadap kemampuan sosialisasi pada pasien isolasi sosial di RSJD Dr. RM. Soedjarwadi Provinsi Jawa Tengah.
\end{abstract}

Kata kunci : Kemampuan sosialisasi, TAK permainan kuartet, isolasi sosial.

\section{THE EFFECT OF TAK IMPLEMENTATIONS : THE QUARTET GAMES CONCERING WITH THE SOCIALIZATION SKILLS IN SOCIAL ISOLATION PATIENTS}

\begin{abstract}
One of the negative skizofrenia indication is sosial isolation. The incidence of mental disorders reached 2.3 per cent of the population. The steps which can be given for the patient's facilitate with social relation problems for socializing gradually through group socialization activities in the form of the group activity therapy using a quartet card. The aim of this study was to find out the effect of TAK implementations : the quartet games concering with the socialization skills in social isolation patients at RSJD Dr. RM. Soedjarwadi Central Java. The types of this study is a quasy eksperimen with the research design pre and post test without control. The sample with the sampling of technique purposive sampling 13 respondence. The average age of respondents in this study is 28,54 years with 7 man. The highest of education is SMP (junior high school) with 6 person or 46,2\%. The highest of respondents work is a jobless 8 person or (61,5\%). The socialization skills before the quartet quiz game intervention were classified less than 7 or (53,8\%). While for the socialization ability after the quartet quiz game intervention was increased where the good socialization ability of 10 person (76,9\%), and the decrease in the socialisation ability was less than 1 person(7,7\%). The result of statistical test with wilcoxon obtained value p-value 0,003 or $(\alpha<0,05)$. There is the impactvof TAK: quartet game on socialization skills in social isolation patients at RSJD Dr. RM. Soedjarwadi Central Java.
\end{abstract}

Keywords : Socialization skills, TAK quartet games, social isolation. 


\section{PENDAHULUAN}

Kesehatan jiwa adalah kondisi jiwa seseorang yang terus tumbuh berkembang secara fisik, mental, spiritual, dan sosial serta mempertahankan keselarasan dalam pengendalian diri, serta terbebas dari stres yang serius sehingga individu tersebut menyadari kemampuan yang dimiliki dapat mengatasi tekanan dan mampu memberikan kontribusi untuk komunitasnya. Kesehatan jiwa bukan hanya tidak ada gangguan jiwa, melainkan mengandung berbagai karakteristik yang positif yang menggambarkan keselarasan dan keseimbangan kejiwaan yang mencerminkan kedewasaan pribadinya (Menurut UU No. 18 Tahun 2014 Tentang Kesehatan Jiwa).

Data World Health Organization (WHO) 2012, terdapat sekitar 60 juta orang terkena bipolar, 47,5 juta orang terkena dimensia, 35 juta orang terkena depresi, serta 21 juta orang terkena skizofrenia. Dengan berbagai faktor penyebab seperti faktor biologis, faktor psikologis, dan faktor sosial. Hal tersebut menunjukkan bahwa masalah gangguan jiwa di dunia menjadi masalah yang sangat serius dan menjadi masalah kesehatan global.

Menurut catatan hasil Riset Kesehatan Dasar (Riskesdas) tahun 2013, menunjukkan prevalensi gangguan jiwa berat di Indonesia rata-rata sebesar 1,7 permil dari 1.027 .763 penduduk atau sebanyak 1.728 jiwa. Sedangkan angka kejadian gangguan jiwa di daerah Jawa Tengah tergolong tinggi, dimana totalnya adalah 2,3 permil dari jumlah penduduk. Apabila dilihat menurut provinsi, prevalensi gangguan jiwa berat paling tinggi terjadi di Provinsi Daerah Istimewa Yogyakarta (DIY) dan Aceh yang menunjukkan 2,7 permil penduduk mengalami gangguan jiwa berat.

Berdasarkan data yang diambil dari hasil studi pendahuluan, di RSJD Dr. RM. Soedjarwadi Provinsi Jawa Tengah pada bulan Maret 2018, dari data Rekam Medik didapatkan bahwa data pasien gangguan jiwa dengan Skizofrenia pada tahun 2015 sebanyak 751 jiwa, tahun 2016 sebanyak 853 jiwa, tahun 2017 sebanyak 981 jiwa, dan pada tahun 2018 sejak bulan Januari sampai Februari 365 jiwa. Jumlah pasien
Skizofrenia di Rumah Sakit Jiwa Daerah Dr. RM. Soedjarwadi Provinsi Jawa Tengah pada empat tahun terakhir ini terus mengalami peningkatan. Dalam satu tahun terakhir terhitung pada bulan Januari 2017 sampai dengan bulan Februari 2018 pasien yang mengalami gangguan jiwa isolasi sosial di bangsal Dewandaru sebanyak 8 orang, bangsal Flamboyan sebanyak 17 orang, bangsal Geranium sebanyak 12 orang, dan bangsal Helikonia sebanyak 6 orang (Data Rekam Medis RSJD. Dr. RM. Soedjarwadi Provinsi Jawa Tengah, 2018).

Pasien dengan isolasi sosial mengalami gangguan dalam berinteraksi dan mengalami perilaku tidak ingin berkomunikasi dengan orang lain, lebih menyukai berdiam diri, dan menghindar dari orang lain. Dalam mengatasi masalah gangguan interaksi pada pasien gangguan jiwa khususnya pasien isolasi sosial dapat dilakukan tindakan keperawatan dengan tujuan untuk melatih pasien melakukan interakasi sosial sehingga pasien merasa nyaman ketika berhubungan dengan orang lain (Berhimpong, Sefty \& Michael, 2016). Jika isolasi sosial tidak teratasi maka akan memberikan dampak seperti narcissisme atau mudah marah, melakukan hal yang tak terduga atau impulsivity, memberlakukan orang lain seperti objek, halusinasi, defisit perawatan diri dan yang paling fatal pasien melakukan bunuh diri (Purwanto, 2015).

Langkah yang dapat dilakukan perawat dalam memberikan asuhan keperawatan kepada pasien isolasi sosial secara komprehensif meliputi terapi individu, terapi kelompok, dan terapi keluarga maupun komunitas. Terapi aktivitas kelompok merupakan salah satu tindakan keperawatan untuk pasien gangguan jiwa. Terapi ini adalah terapi yang pelaksanaannya merupakan tanggung jawab penuh dari seorang perawat. Oleh karena itu seorang perawat khususnya perawat jiwa harus mampu melakukan terapi aktivitas kelompok secara tepat dan benar (Fauzan, 2011).

Terapi aktivitas kelompok menggunakan kartu kuartet merupakan salah satu terapi aktivitas kelompok yang diberikan untuk memfasilitasi pasien dengan masalah hubungan sosial untuk melakukan sosialisasi secara bertahap melalui 
kegiatan permainan sosialisasi kelompok. Media kartu kuartet termasuk media dua dimensi dan media grafis. Kartu kuartet lebih dikenal sebagai suatu bentuk permainan kartu yang dimainkan oleh dua sampai empat orang pemain. Permainan kartu kuartet merupakan salah satu permainan kartu yang dapat digunakan untuk memotivasi dan meningkatkan kemampuan berinteraksi. Keberhasilan terapi aktivitas kelompok permainan kuartet dapat dilihat dari sikap pasien selama mengikuti kegiatan (Wiastuti \& Mamnuah, 2011).

Berdasarkan wawancara yang dilakukan oleh peneliti kepada beberapa perawat jiwa yang ada di RSJD Dr. RM Soedjarwadi Provinsi Jawa Tengah terapi yang diberikan kepada pasien isolasi sosial salah satunya yaitu terapi aktivitas kelompok, namun penerapan terapi aktivitas kelompok permainan kuartet masih jarang dilakukan walaupun media yang digunakan sudah tersedia. Alasan yang diungkapkan oleh perawat diantaranya adalah keterbatasan waktu dan tenaga, karena pada shif pagi perawat sudah mempunyai peranan tugas masing-masing. Terapi aktivitas kelompok yang sering diberikan kepada pasien meliputi latihan berkenalan, bercakap-cakap, bercerita, dan menulis pengalaman pribadi.

Pemberian asuhan keperawatan dengan menerapkan terapi aktivitas kelompok sosialisasi juga perlu diterapkan pada pasien isolasi sosial untuk meningkatkan kemampuan pasien dalam melakukan interaksi sosial karena dengan pendekatan secara berkelompok memungkinkan pasien untuk saling mendukung, belajar menjalin hubungan interpersonal, merasakan kebersamaan dan dapat memberikan masukan terhadap pengalaman masing-masing pasien, sehingga dengan adanya latihan bersosialisasi secara kelompok terjadi peningkatan pada kemampuan pasien dalam bersosialisasi dengan orang lain (Syafrini, Budi \& Yossie, 2015).

Hasil penelitian sebelumnya oleh Sunusi (2014), yang melakukan penelitian tentang Pengaruh terapi aktivitas kelompok sosialisasi terhadap kemampuan komunikasi verbal pasien menarik diri di rumah sakit daerah Madani Palu, didapatkan hasil bahwa ada pengaruh yang signifikan pada terapi aktivitas kelompok sosialisasi terhadap kemampuan komunikasi verbal pasien menarik diri. Sedangkan penelitian dari (Berhimpong, Sefty \& Michael, 2016), yang meneliti tentang Pengaruh latihan keterampilan sosialisasi terhadap kemampuan berinteraksi pasien isolasi sosial di RSJ Prof. Dr. V. L. Ratumbuysang Manado, mendeskripsikan mengenai perbedaan tingkat kemampuan interaksi pada pasien isolasi sosial sebelum dan sesudah dilakukan latihan sosialisasi. Hasil ini menunjukkan bahwa $\mathrm{H}_{0}$ ditolak atau terdapat pengaruh latihan sosialisasi terhadap kemampuan berinteraksi pasien isolasi sosial.

Sejalan dengan penelitian yang dilakukan oleh (Yusuf, Khoridatul \& Yustina, 2009) yang melakukan penelitian tentang Terapi Aktivitas Kelompok Sosialisasi (TAKS) sessi 6 meningkatkan kemampuan bekerjasama anak retardasi mental, dengan jumlah sampel 24 anak retardasi mental, menunjukkan hasil penelitian pada kelompok perlakuan mempunyai kemampuan sosialisasi cukup dan kurang masing-masing sebanyak 5 anak (50\%) dan kelompok kontrol menunjukan bahwa sebagian besar memiliki kemampuan sosialisasi kurang sebanyak 6 anak (60\%) dan cukup sebanyak 4 anak (40\%). Dari semua data yang didapat, maka peneliti tertarik untuk mengetahui lebih lanjut mengenai pengaruh penerapan TAK : permainan kuartet terhadap kemampuan sosialisasi pada pasien isolasi sosial di RSJD Dr. RM. Soedjarwadi Provinsi Jawa Tengah.

\section{METODE}

Jenis penelitian ini adalah quasy eksperimen dengan desain penelitian pre and post test without control, efektifitas perlakuan dimulai dengan cara membandingkan nilai post test dengan pre test dan hanya melakukan intervensi pada satu kelompok tanpa pembanding (Dharma, 2011). Pada penelitian ini populasinya adalah semua pasien skizofrenia dengan isolasi sosial di ruang rawat inap Dewandaru, Flamboyan, Geranium, dan Helikonia RSJD Dr. RM. Soedjarwadi Provinsi Jawa Tengah pada bulan Januari tahun 2017 sampai bulan Februari tahun 2018 sebanyak 43 pasien.Teknik sampel yang digunakan adalah purposive sampling. Jumlah sampel pada penelitian ini sebanyak 13 responden. 
Pengambilan sampel sesuai dengan kriteria inklusi yaitu pasien yang mengalami isolasi sosial yang sedang di rawat, batas umur 20-35 tahun, lama rawat 7-14 hari, sehat secara fisik, dan mampu komunikasi dan sudah kooperatif, sedangkan kriteria eksklusi yaitu pasien dengan isolasi sosial yang mengalami sakit fisik.

Instrumen yang digunakan dalam penelitian ini adalah lembar observasi TAK permainan kuartet sebanyak 12 item pernyataan dan lembar observasi kemampuan sosialisasi sebanyak 15 item penyataan yang diisi langsung oleh peneliti dan asisten peneliti berdasarkan pengamatan pada responden. Penelitian ini menggunakan uji statistik Wilcoxon. Pada penelitian ini menggunakan taraf signifikansi sebesar 0,05.

\section{HASIL}

Adapun karakteristik responden sebagai berikut:

Tabel 1.

Rerata umur responden $(\mathrm{n}=13)$

\begin{tabular}{ccccc}
\multicolumn{5}{c}{ Rerata umur responden $(\mathrm{n}=13)$} \\
\hline \multirow{2}{*}{ Umur } & Umur Responden $(\mathrm{Th})$ \\
& Min-Max & Mean & Modus & SD \\
\cline { 2 - 5 } & $18-35$ & 28,54 & 29 & 5,076 \\
\hline
\end{tabular}

Tabel 1 menunjukkan bahwa rata-rata umur responden yaitu 28,54 $\pm 5,076$.

Tabel 2.

Karakteristik responden $(n=13)$

\begin{tabular}{lcc}
\hline \multicolumn{1}{c}{ Karakteristik } & \multicolumn{2}{c}{ Distribusi } \\
\cline { 2 - 3 } & $\mathrm{f}$ & $\%$ \\
\hline Jenis kelamin & 7 & 53,8 \\
Laki-laki & 6 & 46,2 \\
Perempuan & & \\
\hline Pendidikan & 2 & 15,4 \\
SD/ Sederajat & 6 & 46,2 \\
SMP/ Sederajat & 4 & 30,8 \\
SMA/ Sederajat & 1 & 7,7 \\
Akademik/ Sederajat & & \\
\hline Pekerjaan & 8 & 61,5 \\
\hline Tidak Bekerja & 5 & 38,5 \\
\hline Buruh & & \\
\hline
\end{tabular}

Tabel 2 menunjukkan bahwa mayoritas jenis kelamin responden adalah laki-laki, berpendidikan SMP/ atau sederajat, tidak bekerja

Tabel 3.

Kemampuan Sosialisasi Pasien Isolasi Sosial sebelum dan sesudah penerapan TAK Permainan Kuartet $(n=13)$

\begin{tabular}{ccccc}
\hline Kemampuan Sosialisasi & \multicolumn{2}{c}{ Sebelum } & \multicolumn{2}{c}{ Sesudah } \\
\cline { 2 - 5 } & f & $\%$ & f & $\%$ \\
\hline Kurang & 7 & 53,8 & 1 & 7,7 \\
\hline Sedang & 6 & 46,2 & 2 & 15,4 \\
\hline Baik & 0 & 0 & 10 & 76,9 \\
\hline
\end{tabular}

Tabel 3 menunjukkan mayoritas kemampuan sosialisasi sebelum dilakukan intervensi TAK Permainan Kuartet mempunyai kemampuan sosialisasi kurang dan sesudah dilakukan intervensi TAK Permainan Kuartet mayoritas responden mempunyai kemampuan sosialisasi baik. 
Tabel 4.

Hasil Analisis Bivariat Pengaruh Penerapan TAK Permainan Kuartet Terhadap Kemampuan Sosialisasi Pada Pasien Isolasi Sosial $(\mathrm{n}=13)$

Kemampuan Sosialisasi

\begin{tabular}{|c|c|c|c|c|c|c|c|c|c|c|c|c|c|c|}
\hline \multirow{4}{*}{ TAK } & \multicolumn{4}{|c|}{ Sebelum } & \multicolumn{6}{|c|}{ Sesudah } & \multirow{3}{*}{\multicolumn{2}{|c|}{ Baik }} & \multirow{3}{*}{ Total } & \multirow[b]{4}{*}{$P$} \\
\hline & Kuran & Sedang & $\mathrm{B}$ & & & $\overline{\text { otal }}$ & & $\overline{\text { ang }}$ & & ang & & & & \\
\hline & $\mathrm{g}$ & & & & & & & & & & & & & \\
\hline & $\%$ & $\%$ & $\mathrm{f}$ & $\%$ & $\mathrm{f}$ & $\%$ & $\mathrm{f}$ & $\%$ & $\mathrm{f}$ & $\%$ & $\mathrm{f}$ & $\%$ & $\%$ & \\
\hline $\begin{array}{l}\text { Belum } \\
\text { Mampu }\end{array}$ & $\begin{array}{ll}2 & 15,4\end{array}$ & 15,4 & 0 & 0 & 4 & 30,8 & 1 & 7,7 & 1 & 7,7 & 2 & 15,4 & $\begin{array}{ll}4 & 30,8\end{array}$ & $\begin{array}{l}\text { Value } \\
0,003\end{array}$ \\
\hline
\end{tabular}

Hasil analisa dengan uji Wilcoxon test diperoleh nilai $p$-value $=0,003 \quad(\alpha<0,05)$, sehingga terdapat berbedaan kemampuan sosialisasi antara pre dan post Penerapan TAK Permainan Kuartet yang berarti bahwa Ho ditolak dan Ha diterima sehingga ada Pengaruh Penerapan TAK Permainan Kuartet terhadap kemampuan sosialisasi pada pasien Isolasi Sosial di RSJD Dr. RM. Soedjarwadi Provinsi Jawa Tengah.

\section{PEMBAHASAN}

\section{Umur}

Hasil penelitian ini menunjukkan bahwa semua responden berada dalam rentang umur dewasa muda, diperoleh bahwa rata-rata umur responden pada tabel 1 adalah 28,54 tahun. Hasil ini didukung oleh Efendi, Surya., Atih Rahayuningsih \& Wan Muharyati (2012), mayoritas responden dengan riwayat isolasi sosial berumur 25 - 40 tahun (dewasa akhir) sebanyak 6 orang (60\%). Hampir 90\% pasien yang mengalami pengobatan skizofrenia berumur antara 15 - 55 tahun (Kaplan \& Sadock, 2010). Umur berhubungan dengan pengalaman seseorang dalam menghadapi berbagai macam stresor, kemampuan memanfaatkan sumber dukungan dan keterampilan dalam mekanis mekoping.

Wakhid, Hamid dan Daulima (2013), Individu dalam kehidupannya memiliki tugas-tugas perkembangan sesuai tingkat umurnya. Tugas perkembangan yang tidak dapat diselesaikan dengan baik dapat menjadi stresor untuk perkembangan berikutnya dan jika stresor tersebut menumpuk sangat berisiko mengalami gangguan jiwa. Kondisi tersebut akan menyebabkan individu merasa rendah diri dan apabila berlangsung lama akan menjadi harga diri rendah kronis.

Hal ini disebabkan pada masa dewasa merupakan masa kematangan dari aspek kognitif, emosi, dan perilaku. Kegagalan yang dialami seseorang untuk mencapai tingkat kematangan tersebut akan sulit memenuhi tuntutan perkembangan pada umur tersebut dapat berdampak terjadinya gangguan jiwa (Yusuf, 2010). Pendapat tersebut didukung oleh Stuart (2009) yang menyatakan bahwa umur merupakan aspek social budaya terjadinya gangguan jiwa dengan risiko frekuensi tertinggi mengalami gangguan jiwa yaitu pada umur dewasa.

\section{Jenis kelamin}

Tabel 2 menunjukkan bahwa jenis kelamin responden pada penelitian ini sebagian besar adalah laki-laki sebanyak 7 orang (53,8\%). Hasil ini didukung oleh penelitian Berhimpong, Eyvin., Sefty Rompas \& Michael Karundeng (2016) yang menyatakan bahwa laki-laki lebih mungkin memunculkan gejala negatif dibandingkan perempuan dan perempuan tampaknya memiliki fungsi sosial yang lebih baik daripada laki-laki. Dalam penelitian ini responden dengan jenis kelamin laki-laki sebanyak 17 orang $(56,7 \%)$ danjeniskelaminperempuansebanyak 13 orang $(43,3 \%)$.

Jenis kelamin merupakan bagian dari aspek sosial budaya faktor predisposisi dan presipitasi terjadinya gangguan jiwa. Fausiah \& Widury, (2005) dalam penelitiannya yang menunjukkan bahwa laki-laki lebih mungkin memunculkan gejala negatif dibandingkan wanita dan wanita tampaknya memiliki fungsi sosial yang lebih baik daripada laki-laki. 
Didukung pula oleh pendapat Sinaga (2007), yang menyatakan prevalensi Skizofrenia berdasarkan jenis kelamin, ras dan budaya adalah sama. Dimana wanita cenderung mengalami gejala yang lebih ringan, lebih sedikit rawat inap dan fungsi sosial yang lebih baik di komunitas dibandingkan dengan lakilaki. Laki-laki lebih banyak mengalami isolasi sosial karena disebabkan tuntutan terhadap tanggung jawab atau peran yang harus dipenuhi seorang laki-laki didalam keluarga lebih tinggi disbanding perempuan, sehingga stresor yang dialami juga lebih banyak.

\section{Pendidikan}

Tabel 2 menunjukkan bahwa pendidikan responden pada penelitian ini sebagian besar adalah SMP sebanyak 6 orang (46,2\%). Hasil ini didukung oleh penelitian Wakhid, Hamid, dan Daulima (2013) menyatakan bahwa tingkat pendidikan sangat mempengaruhi cara individu berperilaku, membuat keputusan dan memecahkan masalah, serta mempengaruhi cara penilaian klien terhadap stresor. Dalam penelitian ini, tingkat pendidikan dibagi kedalam empat kategori, yaitu SD/Sederajat $(15,4 \%)$, SMP/ Sederajat (46,2\%), SMA/ Sederajat $(30,8 \%)$, dan Akademik/ Sederajat $(7,7 \%)$.

Johannes (2008) menyatakan bahwa tingkat pendidikan seseorang mempengaruhi daya tahannya dalam menghadapi stres. Seseorang yang berpendidikan rendah lebih mudah mengalami gangguan psikologis, karena selalu mengalami kesulitan dalam menerima keadaan dirinya. Hal tersebut berdampak terhadap terjadinya gangguan jiwa. Makin tinggi tingkat pendidikan seseorang makin tinggi keberhasilannya melawan stres. Orang yang pendidikannya tinggi lebih mampu mengatasi masalah daripada orang yang pendidikannya rendah. Pendidikan bagi seseorang merupakan pengaruh dinamis dalam perkembangan jasmani, jiwa, perasaan sehingga tingkat pendidikan yang berbeda akan member jenis pengalaman yang berbeda juga.

\section{Pekerjaan}

Karakteristik responden berdasarkan pekerjaan pada tabel 2 menyebutkan bahwa sebagian besar responden penelitian ini mayoritas dahulunya tidak bekerja atau bahkan mengalami kehilangan pekerjaan $(61,5 \%)$.
Hasil ini didukung oleh pernyataan Lesmanawati (2012) yang menyatakan bahwa pasien yang memiliki pekerjaan cenderung akan lebih memperhatikan kualitas kesehatannya dibandingkan pasien yang tidak memiliki pekerjaan. Townsend (2009) menyatakan bahwa salah satu faktor sosial yang menyebabkan tingginya angka gangguan jiwa termasuk skizofrenia adalah tingkat sosial ekonomi rendah. Yosep (2010), menjelaskan bahwa seseorang akan mengalami gangguan jiwa atau penyimpangan perilaku apabila banyaknya faktor sosial di lingkungan yang akan memicu munculnya stres pada seseorang.

Kemampuan Sosialisasi Sebelum Perlakuan Berdasarkan tabel 3 kemampuan sosialisasi pada pasien isolasi sosial sebelum diberikan TAK Permainan Kuartet sebanyak 6 orang $(46,2 \%)$ sedang dan 7 orang $(53,8 \%)$ kemampuan sosialisasi kurang. Hasil ini didukung oleh penelitian Sunusi, Happy Cahyani (2014), yang mengasumsikan bahwa masih banyaknya komunikasi verbal yang tidak baik karena belum terbina hubungan saling percaya antara peneliti dan klien sehingga klien tidak mau berkomunikasi.

Keliat (2010) juga menambahkan bahwa pada awalnya mungkin klien hanya akrab dengan perawat, tetapi setelah itu perawat harus membiasakan klien untuk dapat berinteraksi secara bertahap dengan orang-orang disekitarnya. Intervensi yang konsisten akan meningkatkan kemampuan klien dalam berkomunikasi. Hal ini juga dipengaruhi oleh penguatan berupa pujian yang diberikan atas hasil yang telah dicapai klien yang juga semakin memotivasi klien untuk mau bergabung dengan klien lainnya.

\section{Kemampuan Sosialisasi Sesudah Perlakuan}

Setelah diberikan TAK Permainan Kuartet dapat dilihat pada tabel 4.6 kemampuan sosialisasi pada pasien isolasi sosial terjadi peningkatan dimana kemampuan sosialisasi yang baik 10 orang $(76,9 \%)$, kemampuan sosialisasi yang sedang 2 orang $(15,4 \%)$, dan penurunan pada kemampuan sosialisasi yang kurang menjadi 1 orang $(7,7 \%)$. Hal ini terjadi karena sudah terbina hubungan yang baik dan akrab antara peneliti dan responden. Sesuai dengan teori Budyatna \& Ganiem (2011) yang mengatakan bahwa hubungan akrab ditandai 
dengan keramatamahan dan kasih sayang, kepercayaan, pengungkapan diri, dan tanggung jawab.

Hubungan akrab yang terjalin antar peneliti dan klien disebabkan karena peneliti dan klien sudah menghabiskan waktu bersama-sama cukup lama yaitu \pm 7 hari sehingga klien merasa peneliti seperti teman sendiri dan muncul rasa sayang, kepercayaan sehingga dapat menceritakan pengalaman pribadi dan juga rasa tanggung jawab untuk tetap menjaga hubungan bertemanan. Hal ini sesuai dengan teori Budyatna \& Ganiem (2011) yang mengatakan bahwa satu cara sahabat menyatakan kesukaannya ialah melalui cara menghabiskan waktu bersama-sama entah jalan-jalan atau ngobrol.

Sunusi, Happy Cahyani (2014), beranggapan bahwa peningkatan kemampuan komunikasi verbal pada klien menarik diri setelah dilakukan TAK juga bisa terjadi karena selama proses TAK melibatkan banyak orang dalam satu kelompok sehingga klien dapat mengutarakan perasaan dan pikiran kepada teman-teman dalam satu kelompok kemudian teman-teman dalam satu kelompok bisa memberikan respon yang positif setelah klien mengutarakaanya.

Hasil ini berarti bahwa kebanyakan pasien skizofrenia di Rumah Sakit Jiwa Daerah Dr. RM. Soedjarwadi Provinsi Jawa Tengah sebelum diberikan TAK Permainan Kuartet mempunyai tingkat kemampuan sosialisasi tergolong kurang. Penelitian ini dilakukan dengan memberikan TAK Permainan Kuartet. Hasil observasi pada saat pelaksanaan penelitian, terdapat 13 pasien yang mengikuti prosedur TAK secara lengkap mulai dari tahap persiapan sampai terminasi. TAK dalam penelitian ini dilaksanakan tujuh hari berturutturut. Kemampuan sosialisasi pada pasien isolasi sosial setelah diberikan TAK permainan kuartet mengalami peningkatan yaitu menjadi $76,9 \%$.

Hasil ini menunjukkan bahwa TAK sosialisasi permainan kuartet merupakan suatu bentuk terapi yang digunakan untuk memfasilitasi pasien dengan masalah hubungan sosial untuk melakukan sosialisasi secara bertahap melalui kegiatan permainan sosialisasi kelompok menggunakan media kartu kuartet untuk meningkatkan kemampuan bekerja sama. Pelaksanaan TAK permainan kuartet bertujuan untuk meningkatkan kemampuan interaksi, bersosialisasi, dan berkerja sama khususnya bagi pasien isolasi sosial (Efendi, Atih \& Wan Muharyati (2012).

Wiastuti \& Mamnuah, (2011), menjelaskan keberhasilan TAK permainan kuartet dapat dilihat dari sikap pasien selama mengikuti kegiatan. Sikap pasien yang akan mempengaruhi yaitu apakah pasien kooperatif, pasien mengikuti kegiatan dari awal sampai selesai, adanya komunikasi dan kontak sosial selama kegiatan, sebaliknya apabila pasien tidak kooperatif, menarik diri, menghindar dari kelompok, menyendiri, komunikasi kurang, dan tidak ada kontak sosial maka keberhasilan TAK sangat minim.

\section{Pengaruh Penerapan TAK Permainan Kuartet Terhadap Kemampuan Sosialisasi}

Berdasarkan tabel 4 menunjukkan bahwa uji Wilcoxon test diperoleh nilai $p$-value $=0,003$ $(\alpha<0,05)$, yang berarti Ha diterima dan Ho ditolak sehingga ada pengaruh Penerapan TAK Permainan Kuartet Terhadap Kemampuan Sosialisasi Pada Pasien Isolasi Sosial di RSJD DR. RM. Soedjarwadi Provinsi Jawa Tengah. Hasil ini didukung oleh penelitian Berhimpong, Eyvin; Sefty Rompas \& Michael Karundeng (2016), dengan judul Pengaruh Latihan Keterampilan Sosialisasi Terhadap Kemampuan Berinteraksi Klien Isolasi Sosial di RSJ Prof. Dr. V. L. Ratumbuysang Manado yang menyatakan ada pengaruh kemampuan berinteraksi pasien isolasi sosial, dari jumlah pasien yang mampu sebelum diberikan latihan keterampilan sosialisasi sebesar 30,0\%, menjadi $83,3 \%$ setelah diberikan latihan keterampilan sosialisasi.

Penelitian Bachtiar (2010) dengan judul Pengaruh TAK Sosialisasi Terhadap Kemampuan Pasien Berinteraksi Sosial Rumah Sakit Khusus Daerah di Provinsi Sulawesi Selatan menunjukkan kemampuan berinteraksi sosial responden sebelum dilakukan intervensi TAK memiliki nilai mean + Std. Deviasi yaitu $5,83+0,82$ dan kemampuan setelah TAK yaitu $9,75+1,871$. Hasil analisa menunjukkan adanya pengaruh yang signifikan dari TAK Sosialisasi terhadap kemampuan berinteraksi sosial dengan $\mathrm{p}=0,000$. 
Pemberian TAK memiliki dampak terhadap interaksi sosial pada pasien isolasi sosial seperti hasil yang tertera pada tabel 4.7. dengan pemberian TAK permainan kuartet secara rutin pasien dapat meningkatkan interaksi dengan orang lain tanpa merasa takut. Dukungan dari keluarga sangat diperlukan, agar pasien merasa dirinya dihargai dan dibutuhkan. Dukungan dari keluarga ini juga dapat membantu pasien mau mengikuti TAK permainan kuartet dan pasien dapat bersosialisasi didalam kelompok maupun lingkungannya saat pulang nanti.

Berdasarkan hasil observasi, saat diberikan TAK permainan kuartet pasien lebih banyak berkomunikasi dengan lingkungannya. Dikarenakan saat prosedur melakukan TAK permainan kuartet pasien harus memperkenalkan diri, meminta kartu dengan sopan, mengucapkan terimakasih saat diberi kartu, dan membacakan isi dari kartu yang dimiliki kepada kelompok. TAK permainan kuartet juga dilakukan secara berkelompok untuk memfasilitasi pasien dalam bersosialisasi, sehingga TAK permainan kuartet yang diberikan peneliti dapat meningkatkan kemampuan sosialisasi pada pasien isolasi sosial.

\section{SIMPULAN DAN SARAN \\ Simpulan}

Karakteristikrespondendalampenelitian ini adalah rerata berumur 28,54 tahun, dengan jenis kelamin terbanyak yaitu laki-laki 7 orang atau 53,8\%. Tingkat pendidikan responden paling banyak adalah SMP/Sederajat 6 orang atau $46,2 \%$, sedangkan pekerjaan responden terbanyak yaitu tidak bekerja 8 orang atau 61,5\%. Pasien isolasi sosial di RSJD Dr. RM. Soedjarwadi Provinsi Jawa Tengah sebelum diberikan TAK permainan kuartet sebagian besar mempunyai kemampuan sosialisasi kurang sebanyak 7 orang atau 52,8\%. Pasien isolasi sosial di RSJD Dr. RM. Soedjarwadi Provinsi Jawa Tengah sesudah diberikan TAK permainan kuartet sebagian besar mempunyai kemampuan sosialisasi baik sebanyak 10 orang atau $76,9 \%$. Ada pengaruh penerapan TAK permainan kuartet terhadap kemampuan sosialisasi pada pasien isolasi sosial di RSJD Dr. RM. SoedjarwadiProvinsiJawa Tengah secarastatistikdengansignifikan ( $p$-value 0,003 atau $\alpha<0,05)$.

\begin{abstract}
Saran
Pemberian asuhan keperawatan dengan menerapkan terapi aktivitas kelompok sosialisasi dengan permainan kuartet perlu diterapkan pada pasien isolasi sosial untuk meningkatkan kemampuan pasien dalam melakukan interaksi sosial sehingga pasien dapat saling mendukung, belajar menjalin hubungan interpersonal, merasakan kebersamaan dan dapat memberikan masukan terhadap pengalaman masing-masing pasien, sehingga kemampuan pasien dalam bersosialisasi dengan orang lain dapat meningkat.
\end{abstract}

\section{DAFTAR PUSTAKA}

Berhimpong, Eyvin., Sefty Rompas \& Michael Karundeng. 2016.Pengaruh Latihan Keterampilan Sosialisasi Terhadap Kemampuan Berinteraksi Klien Isolasi Sosial Di Rsj Prof. Dr. V. L. Ratumbuysang Manado.E-Journal Keperawatan (EKP) Vol. 4 No. 1 Februari 2016. Available from : https://ejournal.unsrat.ac.id/index.php/jk p/article/view/11282. [Diakses : 23 Februari 2018].

Departemen Kesehatan Republik Indonesia. 2015. Available from : http://www.depkes.go.id/resources/dow nload/pusdatin/profil-kesehatanindonesia/profil-kesehatan-Indonesia2015.pdf. [Diakses : 18 Maret 2018].

Dharma, Kelana Kusuma. 2011. Metodelogi Penelitian Keperawatan Panduan Pelaksanaan dan Menerapkan Hasil Penelitian. Jakarta : Trans Info Media.

Efendi, Surya., Atih Rahayuningsih \& Wan Muharyati. 2012. Pengaruh Pemberian Terapi AKtivitas Kelompok Sosialisasi Terhadap Perubahan Perilaku Klien Isolasi Sosial. NERS JURNAL KEPERAWATAN Vol. 8, No 2, Desember 2012 : 105-114. Available from https://scholar.google.co.id/scholar?hl=i d\&as_sdt=0\%2C5\&q=Pengaruh ++ Pemb 
erian+Terapi+Akti+v+itas+Kelompokt Sosialis+asi+Terhadap++Perubahan+Per ilaku++Klien+Isolasi+Sosial++Surya+E fendi+a+\%2C+\&btnG=. [Diakses : 23 Maret 2018].

Fauzan. 2011. Program Terapi Aktifitas Kelompok. Available from : http//ilmukeperawatan.co.id. [Diakses : 12 Maret 2018].

Keliat, Budi Anna \& Akemat, P. 2011. Proses Keperawatan Jiwa. Jakarta : EGC.

2014. Keperawatan

Jiwa : Terapi Aktivitas Kelompok, Ed. 2. Jakarta : EGC.

Kementerian Kesehatan RI. 2016. Pedoman Umum Program Indonesia Sehat dengan Pendekatan Keluarga. Jakarta:Kementerian Kesehatan RI. Available from : http://www.depkes.go.id/resources/dow nload/lain/Buku\%20Program\%20Indone sia\%20Sehat\%20dengan\%20Pendekatan \%20Keluarga.pdf. [Diakses : 28 Februari 2018].

Purwaningsih, Wahyu \& Ina Karlina. 2010. Asuhan Keperawatan Jiwa. Yogyakarta : Nuha Medika.

Riskesdas. 2013. Hasil Riskesdas 2013. Jakarta: Badan Peneliti dan Pengembangan Kesehatan Kementrian RI. Available from : http://www.depkes.go.id/resources/dow nload/general/Hasil\%20Riskesdas\%202 013.pdf. [Diakses : 28 Februari 2018].

RS Jiwa. (2018). Rekam Medik. Rumah Sakit Jiwa Daerah Dr. RM. Soedjarwadi Provinsi Jawa Tengah. Laporan Tahunan Dan Bulanan. Tidak Dipublikasikan

Setiyorini, Indah \&M. Husni Abdullah. 2012. Penggunaan Media Permainan Kartu Kuartet Pada Mata Pelajaran Ips Untuk Peningkatan Hasil Belajar Siswa Di Sekolah Dasar. JPGSD Vol. 01 No. 02 2013, 0-216. Available from : http://jurnalmahasiswa.unesa.ac.id/index .php/jurnal-penelitian- pgsd/article/view/3020/1767. [Diakses : 20 Februari 2018].

Sugiyono. 2014. Metode Penelitian Kuantitatif, Kualitatif, dan $R \& D$. Bandung : Alfabeta.

. 2016. Metode Penelitian Kombinasi (Mixed Methods). Bandung : Alfabeta.

Sunaryo. 2015. Sosiologi Untuk Keperawatan. Jakarta : Bumi Medika.

Sunusi, Happy Cahyani. 2014. Pengaruh Terapi Aktivitas Kelompok Sosialisasi Terhadap Kemampuan Komunikasi Verbal Klien Menarik Diri Di Rumah Sakit Daerah Madani Palu. Available from

http://repository.uksw.edu/handle/12345 6789/12083. [Diaskes : 7 Maret 2018].

Syafrini, Retty Octi., Budi Anna Keliat \& Yossie Susanti Eka Putri. 2015. Efektivitas Implementasi Asuhan Keperawatan Isolasi Sosial Dalam Mpkp Jiwa Terhadap Kemampuan Klien. Jurnal Ners Vol. 10 No. 1 April 2015: 175-182.Available from : https://ejournal.unair.ac.id/JNERS/article/view/2 112/1569. [Diakses : 1 Maret 2018].

Townsend, M. C. (2009). Psychiatric Mental Health Nursing: Consepts Of Care In Evidence-Based Practice. Philadelphia: FA. Davis.

Undang-Undang Republik Indonesia Nomor 18 Tahun 2014 Tentang Kesehatan Jiwa. Available from http://ditjenpp.kemenkumham.go.id/arsi $\mathrm{p} / \mathrm{ln} / 2014 / \mathrm{uu} 18-2014 \mathrm{bt} . \mathrm{pdf}$. [Diakses : 25 Februari 2018]..

WHO. Mental Health System in Jamaica. [online]; 2012 [cited 2014 July 10. Availabe from http://www.who.int/bulletin/ : diakses Maret 2018.

Wiastuti, Arni \& Mamnuah. 2011. Pengaruh Terapi Aktivitas Kelompok Sosialisasi Terhadap Kemampuan Sosialisasi Pada Pasien Isolasi Sosial Di Rumah Sakit Ghrasia Provinsi DIY. Available from : 
http://digilib.unisayogya.ac.id/990/1/NA SKAH\%20PUBLIKASI\%20ARNI\%20 WIASTUTI\%20\%28070201145\%29.pd f. [Diakses : 15 Februari 2018].

Wiyati, Ruti; Dyah Wahyuningsih \& Esti Dwi Widayanti. 2010. Pengaruh Psikoedukasi Keluarga Terhadap Kemampuan Keluarga Dalam Merawat Klien Isolasi Sosial. Jurnal Keperawatan Soedirman (The Soedirman Journal of Nursing) Vol. 5 No. 2, Juli 2010. Available from : http://www.jks.fikes.unsoed.ac.id/index. php/jks/article/view/275/150. [Diakses : 03 Maret 2018].

Yosep, Iyus \& Titin Sutini. 2016. Buku Ajar Keperawatan Jiwa Dan Advance Mental Health Nursing. Bandung : Refika Aditama.
Yusuf, Ah; Khoridatul Bahiyah \& Yustina Barek Ola. 2009. Terapi Aktivitas Kelompok Sosialisasi (TAKS) Sessi 6 Meningkatkan Kemampuan Bekerjasama Anak Retardasi Mental. Available from http://eprints.ners.unair.ac.id/id/eprint/6 27. [Diakses : 6 Maret 2018].

; Rizky Fitryasari PK \& Hanik Endang Nihayati. 2015. Buku Ajar Keperawatan Kesehatan Jiwa. Jakarta : Salemba Medika. 